\title{
Implementasi Penguatan Pendidikan Karakter pada Siswa Kelas Rendah di Sekolah Dasar
}

\author{
Laras Sinta $^{1}$, Yes Matheos Lasarus Malaikosa ${ }^{2 \bowtie}$, Djoko Hari Supriyanto ${ }^{3}$ \\ Pendidikan Guru Sekolah Dasar, Sekolah Tinggi Keguruan dan Ilmu Pendidikan Modern \\ Ngawi, Indonesia(1) \\ DOI: $10.31004 /$ obsesi.v6i4.2326
}

\begin{abstract}
Abstrak
Penelitian bertujuan untuk mengetahui proses penguatan pendidikan karakter yang dilakukan di SDN Gemarang 6 Kedunggalar Ngawi pada siswa kelas rendah. Penelitian ini menggunakan pendekatan kualitatif deskriptif untuk mengetahui secara natural proses penguatan pendidikan karakter. Sumber data dari penelitian kepala sekolah, guru, orang tua dan siswa kelas rendah. Teknik pengumpulan data yang digunakan dalam penelitian ini adalah observasi, wawancara mendalam dengan guru, orang tua dan siswa kelas rendah, dan dokumentasi. Data penelitian diuji keabsahan menggunakan triangulasi data dan informan. Analisis menggunakan teknik analisis melalui pengumpulan data, kondensasi data, penyajian data, dan penarikan kesimpulan. Hasil penelitian menunjukan bahwa proses penguatan pendidikan karakter melalui program pembiasan baik di sekolah maupun di lingkungan keluarga, di sekolah guru menyiapkan model pembelajaran yang mampu menguatkan karakter siswa, sedangkan dalam kegiatan ekstrakurikuler siswa dibiasakan untuk melakukan semua norma dan aturan yang telah menjadi kesepakatan bersama.
\end{abstract}

Kata Kunci: Implementasi Karakter; Implementasi Penguatan Karakter; siswa kelas rendah

\begin{abstract}
The research aims to find out the process of strengthening character education conducted at SDN Gemarang 6 Kedunggalar Ngawi in low-grade students. This research uses a descriptive qualitative approach to find out naturally the process of strengthening character education. Data sources from research of principals, teachers, parents and low-grade students. The data collection techniques used in the study were observation, in-depth interviews with teachers, parents and low-graders, and documentation. The research data was tested for validity using data triangulation and informants. Analysis uses analytical techniques through data collection, data condensation, data presentation, and conclusion withdrawal. The results showed that the process of strengthening character education through refraction programs both in school and in the family environment, in school teachers prepare learning models that are able to strengthen the character of students, while in extracurricular activities students are accustomed to doing all the norms and rules that have become mutual agreement.
\end{abstract}

Keywords: Character Implementation, Character Strengthening Implementation; low grade students

Copyright (c) 2022 Laras Sinta, et al.

$\triangle$ Corresponding author:

Email Address : yesmatheos@stkipmodernngawi.ac.id (Ngawi, Indonesia)

Received 24 October 2021, Accepted 8 February 2022, Published 20 February 2022 


\section{PENDAHULUAN}

Pendidikan merupakan faktor utama yang berperan dalam membentuk pribadi manusia. Dalam Undang-Undang No. 20 Tahun 2003 tentang sistem pendidikan nasional pasal 3 menyebutkan bahwa pendidikan nasional berfungsi mengembangkan kemampuan dan membentuk watak serta peradaban bangsa yang bermartabat dalam rangka mencerdaskan kehidupan bangsa, bertujuan untuk mengenbangkan potensi peserta didik agar menjadi manusia yang beriman bertaqwa kepada Tuhan Yang Maha Esa, berakhlak mulia, sehat, berilmu, cakap, kreatif, mandarin, dan menjadi warga Negara yang demokratis serta bertanggung jawab. Karakter bangsa merupakan aspek penting dari kualitas SDM karena kualitas kerakter bangsa menentukan kemajuan suatu bangsa (Malaikosa, 2021a).

Era modernisasi semakin meningkat terutama di era globalisasi saat ini membutuhkan sumber daya manusia yang berkualitas. Peningkatan kualitas sumber daya manusia adalah syarat mutlak untuk mencapai tujuan pembangunan. Pendidikan adalah sarana untuk meningkatkan kualitas sumber daya manusia. Undang-undang nomor 20 tahun 2003 tentang sistem pendidikan nasional menyebutkan bahwa setiap warga negara mempunyai hak yang sama untuk memperoleh pendidikan yang bermutu. Hal ini merupakan upaya bangsa Indonesia dalam mencerdaskan kehidupan warga negaranya. Pendidikan merupakan kunci penanaman karakter dan akhlak peserta didik. Dalam pembelajaran diajarkan tata krama, sopan-santun, kejujuran, rasa tanggung jawab integritas, disiplin, kerja keras, dan solidaritas. Harapan pemerintah adalah sekolah menjadi laboratorium karakter dan sebagai gudang calon penerus bangsa dan Negara.

Karakter menjadi kunci lahirnya anak bangsa Indonesia yang unggul dan siap memikul beban pembangunan. Saat ini proses pendidikan di Indonesia baru membentuk dan membimbing dalam hal pengetahuan saja, untuk hal pendidikan karakter minim diterapkan dalam pembelajaran. Sering terjadi peserta didik mendapat nilai tinggi dimata pelajaran Agama dan pendidikan kewarganegaraan tetapi belum tentu memiliki nilai karakter yang baik.

Pendidikan karakter merupakan kebutuhan vital yang sangat mendesak menjadi perhatian dari berbagai pihak. Penguatan pendidikan karakter siswa sangat penting dalam di dunia pendidikan. Semakin gencarnya dorongan dari masyarakat akan pentingnya pendidikan karakter menunjukkan ketidakpuasan akan kualitas pendidikan. Pendidikan karakter dianggap sebagai salah satu jalan keluar defisit pendidikan dewasa ini. Menurunnya kualitas moral dalam kehidupan manusia di Indonesia dewasa ini terutama di kalangan siswa sekolah menengah atas menuntut diselenggarakannya pendidikan karakter.

Dalam mengimplementasi penguatan pendidikan karakter perlu direncanakan seperti: (1) mengidentifikasi jenis-jenis kegiatan di sekolah yang dapat direalisasikan pendidikan karakter yang harus dikuasai, dan direalisasikan oleh siswa dalam kehidupannya, maka perlu pada pelaksanaan penguatan pendidikan karakter siswa agar merealisasikan dalam tiga kelompok kegiatan yakni terpadu dalam pembelajaran tematik, terpadu dengan manajemen sekolah, dan terpadu melalui kegiatan pada ekstra kurikuler, (2) dikembangkan dalam materi pembelajaran dengan berbagai jenis-jenis kegiatan di sekolah, (3) dikembangkan rancangan pelaksanaan pada kegiatan di sekolah (tujuan, materi, jadwal, pengajar, evaluasi, dan fasilitas), (4) disiapkan fasilitas pendukung pada pelaksanaan program pembentukan karakter di sekolah. Dalam perencanaan program pendidikan karakter di sekolah mengacu pada jenisjenis kegiatan sekolah untuk mengembangkan tujuan, sasaran kegiatan, substansi kegiatan, pelaksanaan, keorganisasian, waktu, tempat, serta fasilitas pendukung lainnya. Dengan lingkungan keluarga dan masyarakat diupayakan agar dijadikan proses penguatan pendidikan karakter siswa, yaitu ada dukungan dari orang tua siswa, serta tokoh-tokoh masyarakat, tokoh adat, dan pemerintah. Karena perilaku karakter siswa perlu ada pengawalan dari orang tua siswa, lingkungan masyarakat dan pemerintah setempat. Karakter anak itu baik atau tidak tergantung pada kepedulian orang tua siswa di rumah masingmasing. Lebih dikenal adalah orang tua siswa bersikap terbuka kepada keluarga, tokoh 
masyarakat, tokoh adat, dan tokoh pemuda untuk dijadikan sebagai alat kontrol, serta lebih mengenal dan mengetahui perilaku anaknya. Komunikasi antara sekolah (kepala sekolah) dengan orang tua siswa merupakan salah satu realisasi dari akuntabilitas di sekolah. Meskipun kita di sekolah memiliki kesempatan untuk berinteraksi dan harus mempengaruhi siswa untuk kembali melihat dan mengingat nasihat orang tua dan guru di rumah dan di sekolah, serta lingkungan masyarakat. Orang tua siswa diharapkan menjadi panutan yang sangat mulia dan dikembangkan di sekolah sehingga menjadi kegiatan sehari-hari di rumah, di lingkungan masyarakat masing-masing. Hal ini perlu dilakukan melalui komite sekolah, yayasan, juga ada pertemuan orang tua siswa, kunjungan atau kegiatan orang tua siswa yang berhubungan langsung dengan keluarga, dengan tujuan untuk menyamakan pendapat guna membangun karakter siswa di sekolah.

Penguatan pendidikan karakter juga didukung dengan permendikbud nomor 20 tahun 2018 memberikan kewenang kepada sekolah untuk memperkuat karakter siswa melaluli haronisasi olah hati, olah rasa, olah pikir, dan olah raga dengan melibatkan keluarga dan masyarakat sebagai bagian dari Gerakan Nasional, Revolusi Mental, GNRM). Penguatan Pendidikan Karakter perlu mendapat dukungan dari berbagai komponen masyarakat (Dyah, 2017), karena Penguatan Pendidikan Karakter (PPK) sampai pada saat ini belum maksimal, terutama pada sekolah baik pendidikan dasar sampai sekolah menengah atas, dan perguruan tinggi. Sekolah menjadi tempat yang tepat dalam memaksimalkan untuk menanamkan nilai dan akhlak siswa. Proses penguatan karakter di SDN Gemarang 6 melalui pembelajaran yang diajarkan tata karma, sopan-santun, kejujuran, rasa tanggung jawab integritas, disiplin, kerja keras, serta solidaritas. Pendidikan merupakan suatu upaya untuk menamkan akhlak serta sikap seperti seorang manusia yang sebenarnya. (Auliyairrahmah et al., 2021)

Upaya pemerintah serius dalam mengatasi permasalahan karakter anak bangsa melalui Penguatan Pendidikan Karakter. Penguatan Pendidikan Karakter terintegrasi dalam Gerakan Nasional Revolusi Mental, merupakan perubahan pola pikir, perubahan sikap dan tindakan sebagai lebih baik. Dengan demikian, pendidikan karakter bukan mengajarkan mana yang sahih dan mana yang galat, lebih berasal itu, pendidikan karakter menanam kebiasaan (pembiasaan) tanggal hal yang baik shingga siswa menjadi faham (kognitif) wacana yang benar serta yang keliru, bisa menjadi (efektif) nilai yang baik dan biasa saja (psikomotor) (Rahmawati et al., 2021). Dengan istilah pendidikan karakter lainnya yang baik harus melibatkan bukan saja aspek pengetahuan yang baik (pengetahuan moral), akan tetapi jua menjadi menggunakan baik atau mencintai kebaikan (moral feeling), dan sikap yang baik (tindakan moral). Pendidikan karakter pada kebiasaan atau kebiasaan yang dipraktikan terus menerus dan dilakukan (Sofyan, 2018).

Sesuai deskripsi di atas guru adalah menjadi ujung tombak terbentuknya karakter pada peserta didik untuk menyongsong generasi emas. Pendidikan karakter diterapkan pada pembelajaran serta dalam kehidupan sehari-hari selama berada pada sekolah (Julaiha, 2017). Pendidikan karakter dapat diterapkan sesuai dengan kebijakan yang diberikan sekolah. Pendidikan karakter sudah ada mengukir akhlak melalui proses mengetahui yang baik, mencintai yang baik, dan bertindak yang baik, yakni suatu proses pendidikan yang melibatkan aspek kognitif, emosi, dan fisik, jadi akhlak mulia bisa terukir menjadikebiasaan pikiran, hati, dan tangan. pendidikan karakterdi pada dasarnya bertujuan membuat bangsa yang andal, kompetitif, berakhlak mulia, bermoral, bertoleran, bergotong royong, berjiwa patriotik, dinamis, berorientasi pada ilmu pengetahuan dan teknologi yang semuanya dijiwai oleh iman dan takwa untuk tuhan YME sesuai Pancasila (Supranoto, 2015).

Penelitian yang sama juga dilakukan oleh (Prihatmojo et al., 2019) bahwa perkembangan IPTEK telah membawa kemajuan dan kemudahan serta perubahan pada kehidupan manusia. Berbagai manfaatnya dapat terasa pada era sekarang ini dimana semua perlahan beralih dari sesutau yang sederhana menjadi sesuatu yang lebih modern. ilmu pengetahuan dan teknologi yang dapat dicapai, tetapi tanpa diimbangi kualitas moral dan pengamalan nilai keagamaan yang memadai, maka justru akan dapat merusak tataatan 
kehidupan masyarakat itu sendiri. Pendidikan karakter tidak hanya sekedar mengubah tindakan, melainkan juga mengubah rasa dan piker siswauntuk menjadi pribadi yang diharapkan oleh Permendibud No 20 Tahun 2018. Pendidikan karakter bertujuan mengembangkan kemampuan seseorang untuk memberikan keputusan baik-buruk, memelihara apa yang baik, dan mewujudkan kebaikan itu dalam kehidupan sehar-hari dengan sepenuh hati (Komara, 2018). Pendidikan karakter adalah bagaimana cara menanamkan nilai, budi pekerti, moral, dan watak, agar siswa mampu membuat keputusan baik dan buruk dalam kehidupan sehari-hari baik di sekolah maupun di lengkungan keluarga dan masyarakat dengan sepenuh hati. Pembentukan karakter cukup pada aspek pengetahuan (moral knowing) saja, tetapi perlu ada rasa loving the good and moral feeling, serta perilaku yang baik (moral action) (Komara, 2018; Prihatmojo et al., 2019). Pendidikan karakter erat kaitannya dengan habit atau kebiasaan, yang terus-menerus dipraktekkan dan dilakukan (Komara, 2018). Pendidikan karakter di SDN Gemarang 6 sudah dilaksanakan sesuai dengan kurikulum 2013, namun peneliti ingin mengkaji lebih dalam untuk mendapatkan gambaran terkait proses implementasi penguatan pendidikan karakter kelas rendah di SDN Gemarang 6.

Karakteristik siswa kelas rendah di sekolah dasar dapat dibagi menjadi dua, yaitu kelas rendah dan kelas tinggi. Kelas rendah terdiri dari kelas satu, dua, dan tiga, sedangkan kelaskelas tinggi terdiri dari kelas empat, lima, dan enam (Fartdillah et al., 2020). Sedangkan di Indonesia, rentang usia siswa SD, yaitu antara 6 atau 7 tahun sampai 12 tahun. Usia siswa pada kelompok kelas rendah, yaitu 6 atau 7 sampai 8 atau 9 tahun. Siswa yang berada pada kelompok ini termasuk dalam rentangan anak usia dini (Tharaba, 2020). Masa usia dini ini merupakan masa yang pendek tetapi sangat penting bagi kehidupan seseorang. Oleh karena itu, pada masa ini seluruh potensi yang dimiliki anak perlu didorong sehingga akan berkembang secara optimal.

Berkaitan dengan hal tersebut, ada beberapa tugas perkembangan siswa sekolah (Annisa et al., 2020; Fartdillah et al., 2020; Tharaba, 2020) diantaranya: (a) mengembangkan konsep-konsep yang perlu bagi kehidupan sehari-hari, (b) mengembangkan kata hati, moralitas, dan suatu skala, nilai-nilai, (c) mencapai kebebasan pribadi, (d) mengembangkan sikap-sikap terhadap kelompok-kelompok dan institusi-institusi sosial. Beberapa keterampilan akan dimiliki oleh anak yang sudah mencapai tugas-tugas perkembangan pada masa kanak-kanak akhir dengan rentang usia 6-13 tahun (Fartdillah et al., 2020; Tharaba, 2020). Keterampilan yang dicapai diantaranya, yaitu social-help skills dan play skill. Social-help skills berguna untuk membantu orang lain di rumah, di sekolah, dan di tempat bermain seperti membersihkan halaman dan merapikan meja kursi. Keterampilan ini akan menambah perasaan harga diri dan menjadikannya sebagai anak yang berguna, sehingga anak suka bekerja sama (bersifat kooperatif) (Mardiyah, 2019; Tharaba, 2020). Dengan keterampilan ini pula, anak telah dapat menunjukkan keakuannya tentang jenis kelamin, mulai berkompetisi dengan teman sebaya, mempunyai sahabat, mampu berbagi, dan mandiri. Sementara itu, play skill terkait dengan kemampuan motorik seperti melempar, menangkap, berlari, keseimbangan. Anak yang terampil dapat membuat penyesuaian-penyesuaian yang lebih baik di sekolah dan di masyarakat. Anak telah dapat melompat dengan kaki secara bergantian, dapat mengendarai sepeda roda dua, dapat menangkap bola dan telah berkembang koordinasi tangan dan mata untuk dapat memegang pensil maupun memegang gunting.

Pengembangan karakter pada siswa kelas rendah dapat dilakukan dengan cara menciptakan pembelajaran yang memungkinkan siswa berani mengemukakan pendapat, memiliki rasa ingin tahu, memiliki sikap jujur terhadap dirinya dan orang lain, dan mampu menjaga kebersihan diri dan lingkungan . Dalam penguatan pendidikan karakter pada siswa kelas 1 perlu diarahkan sesuai dengan tingkat perkembangannya, misalnya saja memberikan contoh terlebih dahulu oleh guru melalui proses pembiasan sehari-hari (Fartdillah et al., 2020; Tharaba, 2020). Beberapa contoh kegiatan belajar yang dapat dilakukan siswa kelas rendah yaitu; menggolongkan peran anggota keluarga, menerapkan etika dan sopan santun di 
rumah, di sekolah, dan di lingkungan sekitar, menggunakan kosakata geografi untuk menceritakan tempat, menceritakan cara memanfaatkan uang secara sederhana melalui jual beli barang dan menabung, menceritakan masa kecilnya dengan bantuan foto, mengkomunikasikan gagasan dengan satu kalimat, mengekspresikan gagasan artistik melalui kegiatan bernyanyi dan menari, menulis petunjuk suatu permainan, membilang dan menyebutkan banyak benda dan melakukan operasi penjumlahan, pengurangan, perkalian, dan pembagian.

Contoh-contoh tersebut menggambarkan bahwa pembelajaran di sekolah dasar tidak harus selalu dilakukan dengan ceramah saja, tetapi dapat menggunakan beberapa metode mengajar yang memungkinkan siswa beraktivitas tinggi. Berdasarkan uraian tersebut, belajar akan lebih bermakna jika anak mengalami langsung apa yang dipelajarinya dengan mengaktifkan lebih banyak indera, daripada hanya mendengarkan penjelasan dari guru.

Implementasi merupakan suatu aksi atau aktivitas suatu sistem. Implementasi tidak hanya suatu aktivitas, namun suatu kegiatan yang terencana untuk mencapai tujuan. Pendidikan karakter memiliki nilai yang sangat krusial untuk diterapkan pada anak-anak usia Sekolah Dasar sebab pendidikan karakter merupakan suatu proses pendidikan yang memiliki sebuah tujuan pada upaya pengembangan nilai dan perilaku (Pertiwi et al., 2021)

Pendidikan adalah proses pengajaran suatu pengetahuan, keterampilan atau kebiasaan dari satu generasi ke generasi lain dibawah bimbingan seseorang secara langsung atau secara otodidak (belajar sendiri) (Ainun, 2020). Dalam pelaksanaannya, pendidikan dikenal menjadi suatu perjuangan pada bentuk bimbingan serta arah terhadap siswa (Sekolah, 2019). Bimbingan dilakukan guna menghantarkan peserta didik ke arah eksklusif, serta melakukan proses perubahan perilaku atau tindakan ke arah yang lebih baik lagi. ada lima hal yang perlu diperhatikan pada proses pendidikan, diantaranya; perjuangan, bentuk bimbingan, pendidik, peserta didik, tujuan, dan perangkat pembelajaran (Ramdhani, 2014).

Karakter menurut Kamus Besar Bahasa Indonesia mempunyai arti sifat-sifat kejiwaan atau watak seseorang yang membedakan satu dengan yang lainnya. Pendidikan karakter adalah pendidikan tentang karakter atau pendidikan yang mengajarkan hakekat karakter dalam ketiga ranah cipta, rasa dan karsa (Dalyono \& Enny Dwi Lestariningsih, 2017).

Pendidikan karakter diterapkan dalam dua cara, khususnya dengan rencana pendidikan formal atau kegiatan yang dimodifikasi dan program pendidikan nonformal atau latihan penyesuaian (Malaikosa, 2021a). Sebelum menerapkan atau dalam melaksanakan pengajaran karakter untuk anak-anak, ada baiknya untuk membuat rencana atau pengaturan yang sebelumnya (Sari \& Puspita, 2019). Hal ini direncanakan untuk mengatur aset yang berbeda sehingga hasil yang dicapai sesuai dengan apa yang diharapkan secara umum. Pendidikan karakter ditentukan dengan cara komprehensif, sistematik, dan kultural (Prabandari, 2020). Komprehensif di sini menyangkut semua bagian pendidikan, sistematik ditandai oleh adanya keterkaitan antara bagian-bagian pengajaran, sedangkan kultural adalah membangun iklim yang positif, baik di sekolah, di rumah, maupun masyarakat (Baron et al., 2018). Jika pengaturannya telah diatur, pelaksanaan pendidikan karakter dapat diselesaikan dengan mengikut sertakan banyak orang, seperti siswa, guru, sarana dan prasarana, lingkungan setempat, lingkungan rumah/pendidikan, orang tua/pendidikan keluarga (Malaikosa, 2021). Pendidikan karakter tidak merupakan mata pelajaran yang berdiri sendiri, namun dapat terintegrasi pada kurikulum (Nitte \& Bulu, 2020).

Petunjuk untuk mengetahui kemajuan karakter anak adalah dengan melakukan penilaian mendasar. Penilaian dilakukan untuk menentukan pencapaian peningkatan karakter siswa (Khotimah, 2019; Sujatmiko et al., 2019) tujuan program Penguatan Pendidikan Karakter adalah menanamkan nilai-nilai pembentukan karakter bangsa ke peserta didik secara masif dan efektif melalui lembaga pendidikan dengan prioritas nilai-nilai tertentu yang akan menjadi fokus pembelajaran, pemahaman, pengertian, dan praktik (Gestiardi \& Suyitno, 2021) sehingga pendidikan karakter sungguh dapat mengubah perilaku, cara berpikir, dan cara bertindak seluruh bangsa Indonesia menjadi lebih baik dan berintegritas. Penguatan 
Pendidikan Karakter dimulai dari Pendidikan Anak Usia Dini (PAUD), dilanjutkan dengan prioritas pada jenjang pendidikan dasar, yaitu Sekolah Dasar dan Sekolah Menengah Pertama (Khotimah, 2019) gerakan PPK pada usia dini dan jenjang pendidikan dasar ini akan diintegrasikan dengan prioritas nilai dalam Gerakan Nasional Revolusi Mental (GNRM) sehingga terjadi perubahan yang masif dan serentak di seluruh Indonesia.

\section{METODOLOGI}

Dalam melakukan penelitian penguatan pendidikan karakter pada siswa kelas rendah di SDN Gemarang 6, peneliti bertindak sebagai instrumen tumggal dalam pengumpul data utama. Kehadiran peneliti disini dimulai dari observasi, wawancara dan studi dokumentasi. Pernyataan diatas sesuai dengan pendapat (Moleong, 2014). Penelitian kualitatif merupakan pendekatan yang cocok untuk mengetahun proses penguatan pendidikan karakter pada siswa kelas rendah di SDN Gemarang 6, peneliti melakukan observasi terkait proses penguatan pendidikan karakter pada siswa kelas rendah untuk mengamati secara natural di SDN Gemarang 6.

Berdasarkan hasil observasi, peneliti melakukan wawancara dengan kepala sekolah sebagai informan kunci terkait kebijakan penguatan pendidikan karakter untuk anak kelas rendah di SD N Gemarang 6, serta guru dan siswa sebagai bentu triangulasi sumber data penelitian. Selajutnya, peneliti melakukan kajian terkait dokumen pendukung kebijakan yang diturunkan dalan kegiatan penguatan pendidikan di SDN Gemarang 6. Dengan melakukan pengumpulan data tersebut, peneliti dapat memperoleh informasi mengenai fenomena atau proses penguatan pendidikan karakter pada SDN Gemarang 6 tempat penelitian dilakukan. Pemahaman terhadap penguatan pendidikan karakter tersebut bisa ditinjau dari sudut pandang subjek penelitian, untuk mendapatkan pemahaman yang holistik, utuh dan menyeluruh. Sumber data penelitian ini adalah kepala sekolah, guru, dan siswa kelas rendah di SDN Gemarang 6 melalui observasi, wawancara mendalam, dan studi dokumentasi. Dalam proses pengambilan data tersebut peneliti dapat melihat dan mendengar serta bertanya kepada informan yang dilakukan secara sadar dan terarah sehingga menghasilkan jawaban sebagai sumber informasi bagi peneliti. Penentuan informan kunci dalam penelitian ini dilakukan dengan teknik purposive sampling.

Teknik keabsahan data yang digunakan peneliti adalah teknik triangulasi. Analisis data dalam penelitian ini, peneliti membangun hasil wawancara atau pengamatan terhadap proses penguatan pendidikan karakter untuk dijadikan bahan kajian dalam pembahasan. Peneliti membuat pertanyaan terkait proses penguatan pendidikan karakter untuk menggali informasi dari kepala sekolah, guru, dan siswa untuk mengetahui secara komperhensip. Analisis data yang digunakan dalam penelitian peneliti menggunakan model (Miles et al., 2014), yaitu analisis data penelitian kualitatif dapat dilakukan melalui tiga alur kegiatan yang terjadi secara bersamaan, dapat di lihat pada gambar 1.

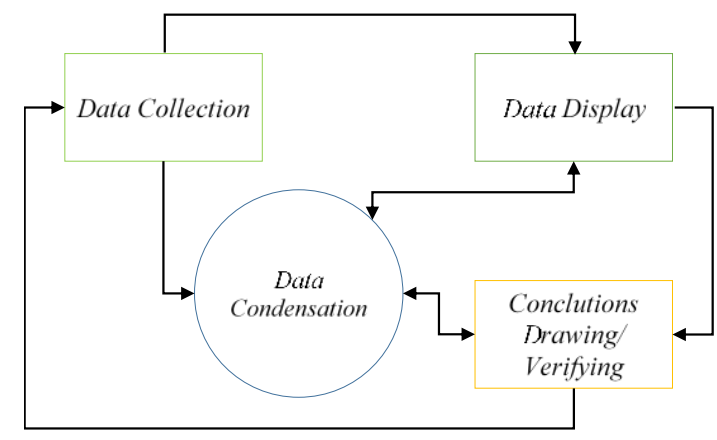

Gambar 1: Komponen Analisis Data: Model Interaktif Sumber: (Miles et al., 2014) 


\section{HASIL DAN PEMBAHASAN}

\section{Strategi Penguatan Pendidikan Karakter pada masa Pandemi Covid-19}

Berdasarkan hasil penelitian menunjukan bahwa proses implementasi penguatan pendidikan karakter di SD Gemarang 6 melalui penanaman nilai karakter pada siswa dalam proses pembelajaran di kelas maupun di luar kelas, hasil wawancara dengan kepala sekolah diperoleh data bahwa proses implementasi PPK di masa pandemi Covid-19 menjadi kendala dalam melakukan penguatan pendidikan sehingga sekolah perlu merencanakan strategi dengan melibatkan orang tua agar proses penguatan karakter tetap berjalan. Pelaksanaan penguatan karakter pada siswa kelas rendah di SDN Gemarang 6 memuat kegiatan penanaman nilai karakter dalam perencanaan pembelajaran daring maupun luring dalam mata pelajaran, dan mengintegrasikan dalam pengembangan diri yang didampingi orang tua apabila proses pembelajaran daring, sedangkan pada proses pembelajaran luring di damping langsung oleh guru di sekolah.

Proses implementasi penguatan pendidikan karakter pada siswa kelas rendah di SDN Gemarang 6 mencangkup nilai religius, kemandirian, integritas, gotong royong, dan nasionalisme. Selengkapnya disajikan pada gambar 1.

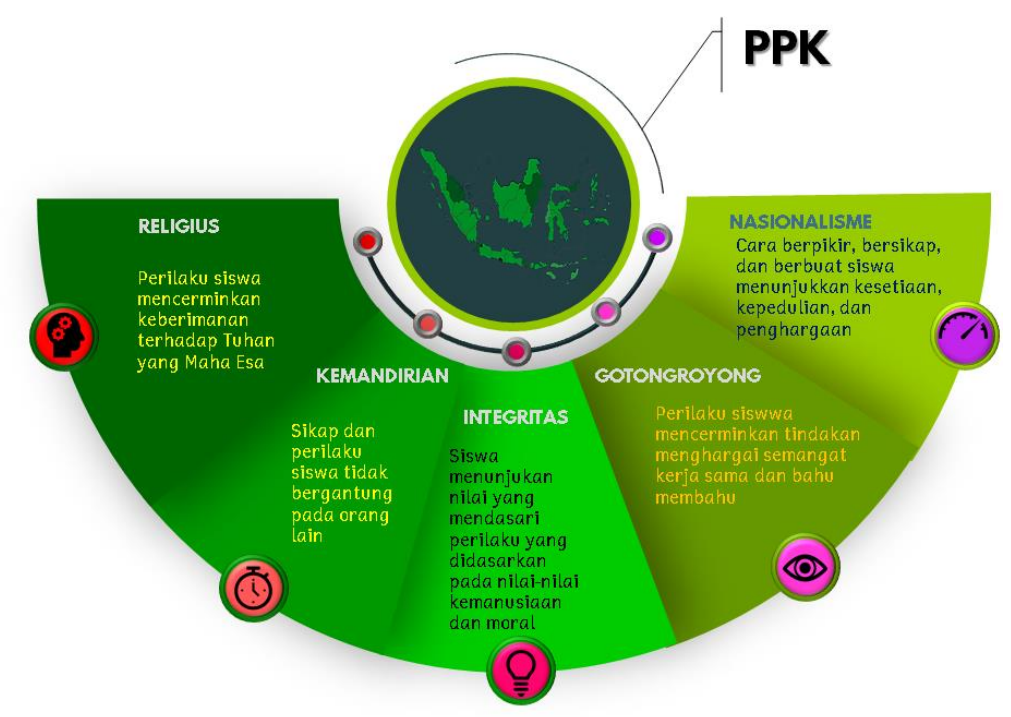

Gambar 2. Proses Penguatan Pendidikan Karakter

(Sumber: Pengemabngan hasil Temuan Penelitian)

\section{Upaya Sekolah Dalam Proses Penguatan Pendidikan Karakter}

Penanaman nilai religius pada siswa kelas rendah di SDN Gemarang mencakup 2 aspek kegiatan yakni; kegiatan kurikuler dan ekstrakulikuler. Kegiatan kurikuler merupakan penanaman nilai religius yang diberikan melalui mata pelajaran agama islam seperti hafalan surat pendek, doa-doa pendek dan fiqih sholat, sedangkan ekstrakulikuler melalui program pembiasaan seperti sholat Dhuha dan dhuhur berjamaah, mengaji, dan berdoa sebelum belajar (gambar 3). Program kurikuler dilakukan oleh guru pengampu mata pelajaran, sedangkan program ekstrakulikuler dilakukan dengan bimbingan guru kelas. Proses penanaman nilai religius melalui pembiasan terprogram untuk dilakukan oleh siswa di sekolah maupun di rumah. Kegiatan pembiasan tersebut dilakukan secara berkesinambungan bertujuan untuk pembentukan karakter siswa dalam semua aktivitas. Peran guru dan orang tua sebagai fasilitator atau pendamping, agar program penguatan pendidikan karakter dapat berjalan dengan baik dan terukur. Hasil penelitian sesuai dengan penelitian Gestiardi \& Suyitno, (2021) yang menjelaskan bahwa proses belajar mengajar, guru mempunyai tugas untuk mendorong, membimbing, dan memberi fasilitas belajar bagi siswa guna mencapai tujuan yang diinginkannya (Mardiyah, 2019) maka nilai-nilai pendidikan karakter harus didasari pada nilai-nilai dan kaidah yang berasal dari agama. 


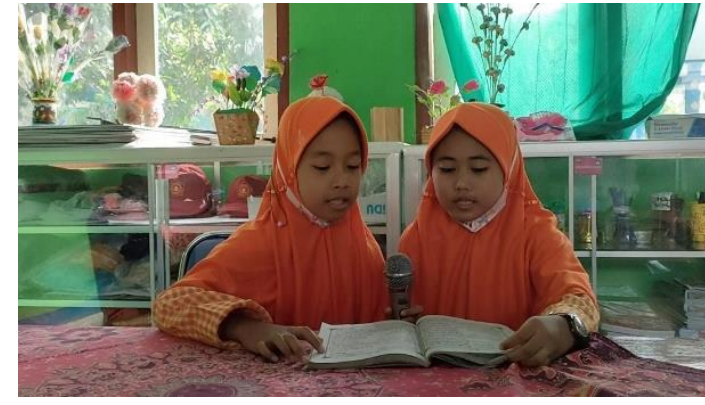

Hafalan Surat Pendek dan Doa-Doa Pendek

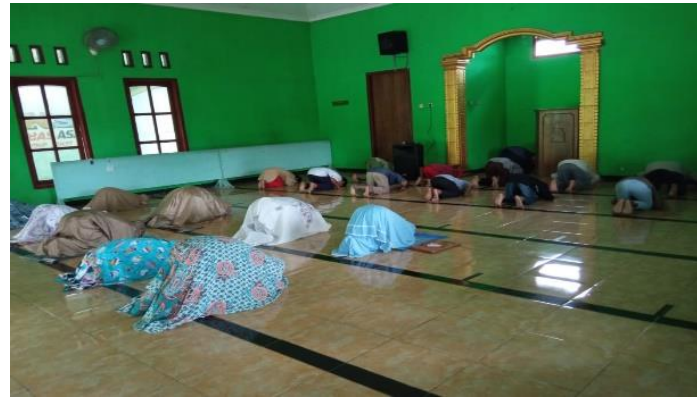

Sholat Dhuha dan Dhuhur Berjamaah

\section{Gambar 3. Penguatan Pendidikan Karakter pada Siswa Kelas Rendah di SDN Gemarang 6}

Penanaman nilai dalam membentuk kemandirian melalui kegiatan pembiasaan yang diprogramkan sekolah, berdasarkan hasil wawancara dengan guru diperoleh data bahwa siswa di biasakan untuk mencuci tangan, menggunakan hand sanitizer, dan menggunakan masker serta mandiri dalam menyelesaikan tugas pembelajaran dengan pengawasan guru dan orang tua. Pembiasan tersebut akan mempengaruhi perilaku sesuai dengan nilai dalam penguatan pendidikan karakter. Hasil penelitian sesuai dengan penelitian yang dilakukan oleh (Mardiyah, 2019; Rahmawati et al., 2021) diterapkan melaui kegiatan mengerjakan tugas yang diberikan guru dan berani meminta maaf kalua berbuat salah.

Penanaman nilai integritas melalui kegiatan ekstrakurikuler seperti kegiatan pramuka dan seni budaya dan pra karya. Siswa di ajarkan untuk menunjukan integritas dalam berbudaya. Budaya merupakan identitas kita sebagai bangsa Indonesia. Berdasarkan hasil wawancara dengan Pembina pramuka diperoleh data bahwa siswa diajarkan tentang kode kehormatan siaga pramuka untuk menjunjung tinggi kejujuran dan tanggung terhadap tugas yang diberikan. Hasil penelitian sesuai dengan penelitian (Khotimah, 2019; Komara, 2018; Supriyanto, 2017) terkait program Penguatan Pendidikan Karakter bertujuan untuk menanamkan nilai-nilai karakter bangsa ke peserta didik secara masif dan efektif melalui lembaga pendidikan dengan prioritas nilai-nilai tertentu menjadi fokus pembelajaran, pemahaman, pengertian, dan praktik, sehingga pendidikan karakter sungguh dapat mengubah perilaku, cara berpikir, dan cara bertindak seluruh bangsa Indonesia menjadi lebih baik dan berintegritas.

Penanaman nilai gotong royong melalui kegiatan pembiasan dalam kehidupan sosial di sekolah. Dalam kegiatan gotong royong siswa belajar untuk menyelesaikan tugas secara bersama-sama dengan penuh tanggung jawab. Siswa terlibat dalam kegiatan jumat bersih dan kegiatan lainnya yang diselenggarakan oleh dinas pendidikan. Gotong royong sudah menjadi budaya bangsa Indonesia yang diwariskan kepada generasi bangsa sehingga perlu di lestarikan. Hasil penelitian didukung dengan penelitian (Khotimah, 2019; Komara, 2018; Mardiyah, 2019) karakter bangsa Indonesia yang terkenal dengan karakter jujur, bertoleransi antar umat beragama, ramah, gotong-royong, rukun, saling menghargai satu sama lain yang sesuai dengan azas kesatuan dan persatuan serta sesuai dengan nilai-nilai Pancasila.

Penanaman nilai nasionalisme melalui kegiatan kurikuler dan ekstrakurikuler. Pada kegiatan kurikuler diintegrasikan dalam mata pelajaran PPkN dan IPS agar siswa memiliki kecintaan terhadap NKRI, melalui pengenalan simbol-simbol negara kesatuan republik Indonesia. Sedangkan dalam kegiatan ekstrakurikuler siswa diwajibkan untuk mengikuti kegiatan pramuka yang telah diprogramkan oleh sekolah. Kegiatan ekstrakurikuler seperti kode kehormatan siaga pramuka. Hasil penelitian didukung dengan penelitian Khotimah, (2019); Komara (2018); Mardiyah (2019) bahwa PPK ini harus mengembangkan lima nilai karakter termasuk diantaranya adalah religius, nasionalisme, kemandirian, gotong royong, dan integritas. 


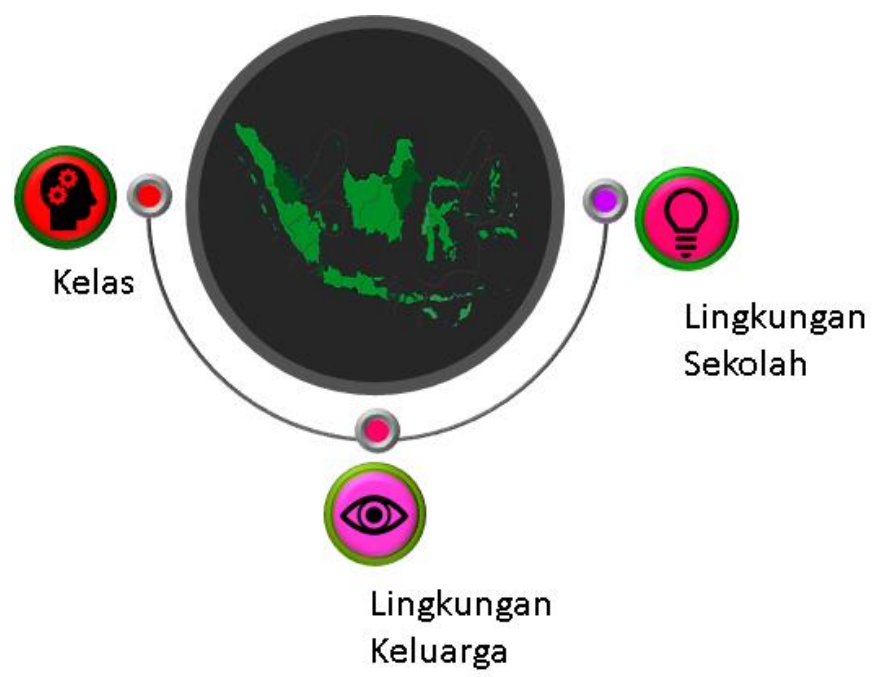

Gambar 4. Pola Penguatan Pendidikan Karakter pada Siswa Kelas Rendah di SDN Gemarang 6

Hasil penelitian ini menemukan pola penguatan pendidikan karakter pada siswa kelas rendah di SDN Gemarang 6 sebagaimana disajikan pada gambar 4. Pola penguatan pendidikan karakter di sekolah kepala sekolah melibatkan orang tua untuk ikut dalam membentuk karakter siswa di rumah. Hal tersebut dilakukan dengan tujuan agar proses penguatan karakter siswa terlaksana secara berkesinambungan.

\section{SIMPULAN}

Penguatan pendidikan karakter yang digunakan oleh SDN Gumarang 6 melalui konsep pembiasaan pada siswa kelas rendah. Konsep pembiasaan dilakukan agar siswa dapat terbiasa dengan kegiatan yang dilakukan di sekolah dan dapat menerapkannya di lingkungan keluarga, agar siswa mendapatkan pengalaman yang baik. Kepala sekolah perlu melakukan sosialisasi terkait program penguatan pendidikan karakter kepada orang tua, agar tujuan tersebut dapat tercapai dengan baik.

\section{UCAPAN TERIMA KASIH}

Peneliti Sampaikan Terima Kasih Kepada Kepala SDN Gumarang 6, Bapak dan Ibu Guru serta Siswa/i yang telah berpatisipasi dalam penelitian ini, semoga hasil penelitian di SDN Gumarang 6 dapat bermanfaat bagi sekolah dan peneliti lain.

\section{DAFTAR PUSTAKA}

Annisa, M. N., Wiliah, A., \& Rahmawati, N. (2020). Pentingnya Pendidikan Karakter Pada Anak Sekolah Dasar Di Zaman Serba Digital. Jurnal Pendidikan Dan Sains, 2(1), 35-48. https://ejournal.stitpn.ac.id/index.php/bintang

Auliyairrahmah, A., Djazilan, S., Nafiah, \& Hartalik, S. (2021). Implementasi Pendidikan Karakter Integritas Sub Nilai Kejujuran melalui Program Kantin Kejujuran di Sekolah Dasar. Edukatif : Jurnal Ilmu Pendidikan, 3(6), 3565-3578.

Baron, A., Bedore, L. M., Peña, E. D., Lovgren-Uribe, S. D., López, A. A., \& Villagran, E. (2018). Research article. American Journal of Speech-Language Pathology, 27(3), 975-987. https://doi.org/10.1044/2018_AJSLP-17-0074

Creswell, J. W. (2012). Educational research: Planning, conducting, and evaluating quantitative and qualitative research. In Educational Research (Vol. 4). https://doi.org/10.1017/CBO9781107415324.004

Dalyono, B., \& Enny Dwi Lestariningsih. (2017). Implementasi penguatan pendidikan karakter di sekolah. Bangun Rekaprima, 3(3), 33-42. 
Fartdillah, K., Hidayat, R., \& Alifah .A, D. (2020). Analisis Desain Pembelajaran SD Kelas Rendah. Fondatia, 4(1), 180-186. https:// doi.org/10.36088/fondatia.v4i1.430

Gestiardi, R., \& Suyitno, S. (2021). Penguatan Pendidikan Karakter Tanggung Jawab Sekolah Dasar Di Era Pandemi. Jurnal Pendidikan Karakter, 1, 1-11. https://doi.org/10.21831/jpk.v0i1.39317

Julaiha, S. (2017). Implementasi Pendidikan Karakter Dalam Pembelajaran. STILISTIKA: Jurnal $\begin{array}{llll}\text { Bahasa, } \quad \text { Sastra, 226-239. } & \text { Pengajarannya, }\end{array}$ https://doi.org/10.33654/sti.v2i1.385

Khotimah, D. N. (2019). Implementasi Program Penguatan Pendidikan Karakter ( PPK ) Melalui Kegiatan 5s Di Sekolah Dasar. Ilmiah Kependidikan, 2(1), 28-31. https://jurnal.umk.ac.id/index.php/pendas/article/view/2928

Komara, E. (2018). Penguatan Pendidikan Karakter dan Pembelajaran Abad 21. SIPATAHOENAN: South-East Asian Journal for Youth, Sports \& Health Education, 4(1), 17-26.

Malaikosa, Y. M. L. (2021a). Penguatan life skills peserta didik dengan pendekatan ekonomi kreatif. $\mathrm{V}(2)$, 300-312. https:// doi.org/10.24252/idaarah.v5i2.24215

Malaikosa, Y. M. L. (2021b). Strategi Kepala Sekolah Dalam Mengimplementasikan Manajemen Berbasis Sekolah Untuk Meningkatkan Mutu Sekolah. Idaarah: Jurnal Manajemen Pendidikan, 5(1). https://doi.org/10.24252/idaarah.v5i1.20270

Mardiyah, S. (2019). Penerapan Pendidikan Karakter Di Sekolah. Edification Journal, 1(1), 127-137. https://doi.org/10.37092/ej.v1i1.89

Miles, B. M., Huberman, A. M., \& Saldana, J. (2014). Qualitative Data Analysis A Methods Sourcebook.

Moleong, J. L. (2014). Metodologi Penelitian Kualitatif: Edisi Revisi. Remaja Rosda Karya.

Nitte, Y. M., \& Bulu, V. R. (2020). Pemetaan Implementasi Pendidikan Karakter di Sekolah Dasar se-Kota Kupang. Jurnal Kependidikan: Jurnal Hasil Penelitian Dan Kajian Kepustakaan Di Bidang Pendidikan, Pengajaran Dan Pembelajaran, 6(1), 38. https://doi.org/10.33394/jk.v6i1.2326

Pertiwi, A. D., Nurfatimah, S. A., Dewi, D. A., \& Furnamasari, Y. F. (2021). Implementasi Nilai Pendidikan Karakter Dalam Mata Pelajaran PKn di Sekolah Dasar. Jurnal Basicedu, 5(5), 4331-4340. https://doi.org/10.31004/basicedu.v5i5.1565

Prabandari, A. S. (2020). Implementasi Pendidikan Karakter Di Sekolah Dasar. Jurnal Pendidikan Dan Konseling (JPDK), 2(1), 68-71. https:// doi.org/10.31004/jpdk.v1i2.586

Prihatmojo, A., Agustin, I. M., Ernawati, D., \& Indriyani, D. (2019). Implementasi Pendidikan Karakter di Abad 21. Prosiding SEMNASFIP, 1(1), 180-186.

Rahmawati, A. D., Supriyanto, D. H., \& Sari, W. R. (2021). Project-Based Learning Model with A Scientific Approach to Mathematics Learning in Covid-19 Pandemic. AL-Ishlah: Jurnal Pendidikan, 13(1), 769-775. https://doi.org/10.35445/alishlah.v13i1.595

Ramdhani, M. A. (2014). Lingkungan Pendidikan dalam Implementasi Pendidikan Karakter. Jurnal Pendidikan UNIGA, 8(1), 112-119. https:// doi.org/10.1177/002218568402600108

Sari, N. K., \& Puspita, L. D. (2019). Implementasi Pendidikan Karakter Di Sekolah Dasar. Jurnal Dikdas Bantara, 2(1). https://doi.org/10.32585/jdb.v2i1.182

Sekolah, L. (2019). Implementasi Pendidikan Karakter melalui Kegiatan Pembelajaran di Lingkungan Sekolah. 5, 173-190. https://doi.org/10.32678/tarbawi.v5i02.2074

SOFYAN, M. (2018). Implementasi Pendidikan Karakter Sofyan Mustoip Muhammad Japar Zulela Ms 2018.

Sujatmiko, I. N., Arifin, I., \& Sunandar, A. (2019). Penguatan Pendidikan Karakter di SD. Jurnal Pendidikan: Teori, Penelitian, Dan Pengembangan, 4(8), 1113. https://doi.org/10.17977/jptpp.v4i8.12684

Supranoto, H. (2015). Implementasi Pendidikan Karakter Bangsa Dalam Pembelajaran Sma. PROMOSI (Jurnal Pendidikan Ekonomi), 3(1), 36-49. https://doi.org/10.24127/ja.v3i1.141

Supriyanto, D. H. (2017). Pengembangan Media Jembatan Zebra Pada Materi Satuan. 70-74.

Tharaba, M. F. (2020). Mencari Model Pendidikan Karakter Di Sekolah. J-MPI (Jurnal Manajemen Pendidikan Islam), 5(1), 66. https://doi.org/10.18860/jmpi.v5i1.8750

Ulfatin, N. (2015). Metode Penelitian Kualitatif di Bidang Pendidikan: Teori dan Aplikasinya. Media Nusa Creative. 